Perspective

\title{
Ecological consequences of human depopulation of rural areas on wildlife: A unifying perspective
}

\author{
Alejandro Martínez-Abraín ${ }^{\mathrm{a}, *}$, Juan Jiménez ${ }^{\mathrm{b}}$, Ignacio Jiménez ${ }^{\mathrm{c}}$, Xavier Ferrer ${ }^{\mathrm{d}}$, Luis Llaneza ${ }^{\mathrm{e}}$, \\ Miguel Ferrer ${ }^{\mathrm{f}}$, Guillermo Palomero ${ }^{g}$, Fernando Ballesteros ${ }^{\mathrm{g}}$, Pedro Galán ${ }^{\mathrm{a}}$, Daniel Oro ${ }^{\mathrm{h}}$ \\ ${ }^{a}$ Universidade da Coruña, Facultad de Ciencias, Grupo de Investigación en Biología Evolutiva (GIBE), Campus da Zapateira s/n, 15071 A Coruña, Spain \\ ${ }^{\text {b }}$ Servicio de Vida Silvestre, Generalitat Valenciana, Ciutat Administrativa 9 d'Octubre, Torre 1, C/Democracia 77, 46018 Valencia, Spain \\ ${ }^{\mathrm{c}}$ IUCN Conservation Translocation Specialist Group, Avda. Suecia 27, 7, 46010 Valencia, Spain \\ d Biodiversity Research Institute (IRBIO), Universitat de Barcelona, Av. Diagonal 643, 08028 Barcelona, Spain \\ ${ }^{\mathrm{e}}$ A.RE.NA Asesores en Recursos Naturales S.L., C/Perpetuo Socorro 12, Entlo. 2-B, 27003 Lugo, Spain \\ ${ }^{\mathrm{f}}$ Applied Ecology Group, Estación Biológica de Doñana, CSIC, Avda. Américo Vespucio s/n, 41092 Sevilla, Spain \\ ${ }^{\mathrm{g}}$ Fundación Oso Pardo, C/San Luis 17, 4 A, 39010 Santander, Spain \\ ${ }^{\mathrm{h}}$ Consejo Superior de Investigaciones Científicas (CEAB), Blanes, Spain
}

\section{A R T I C L E I N F O}

\section{Keywords:}

Human depopulation

Wildlife recovery

Cropland abandonment

Range expansion

Changed human attitudes

Refuge abandonment

Approach to urban areas

Bold behaviour

\begin{abstract}
A B S T R A C T
The depopulation of rural areas by humans (or rural exodus) in southern Europe, and the associated abandonment of cropland, had marked ecological consequences on wildlife, which became evident approximately fifteen years ago. Shrub and tree encroachment, and the expansion of forest birds and the formerly persecuted mammalian ungulates and carnivores, were highlighted as the major consequences of the rural exodus in Italy. In this report, we provide a more integrative view, and show that a rural exodus also explains other ecological phenomena that are usually treated independently. After reviewing the ecological consequences of the rural exodus that has been affecting a large part of Spain during the last six decades, we suggest that this set of ecological consequences also includes the movement of shy-selected predators and large, big game species out of their former ecological refuges, as well as increased frequencies of individuals with bolder-behaviours in recovering populations. We develop a tentative conceptual model linking the increasing approach of wildlife to anthropogenic habitats and human depopulation of rural areas. These links are created by the increasing difficulty to survive and reproduce in recovering, high-predation wild areas, due to mesopredator release and the loss of fear to humans, among other factors. We acknowledge that the recovery of formerly persecuted wildlife in depopulated landscapes has been helped by conservation policies, but we suggest that policies alone cannot explain the observed changes. Finally, we propose that the processes we analyse on a national scale could be taking place in Europe on a continental scale as well, and will most likely occur in the future in other regions of the world, with the current growth in economies.
\end{abstract}

\section{Introduction}

The structure of animal communities is determined by environmental factors such as climate, geography, or species interactions. However, human activity can also play a substantial role in regions in which human presence has a long history of ecosystem alteration and interaction with wildlife, such as the Mediterranean region (see e.g. Blondel and Aronson, 1999). A large-scale depopulation process (rural exodus, hereon) has been taking place in rural parts of Europe since, at least, the 1960s of the 20th century (Pereira and Navarro, 2015;
MacDonald et al., 2000; Robinson and Sutherland, 2002). The ecological consequences and conservation implications of this process have been well identified in some southern European countries, notably Italy, and are known to include a) shrub and tree encroachment on abandoned cropland, and b) the associated expansion of forest birds and formerlypersecuted large mammalian ungulates and carnivores (Farina, 1991, 1997; García-Ruiz et al., 1996; Preiss et al., 1997; Debussche et al., 1999; Falcucci et al., 2007). These processes have been reported to proceed independently of conservation policies (Falcucci et al., 2007).

In this report, we focus on the case of Spain, a southern European

\footnotetext{
* Corresponding author.

E-mail address: a.abrain@udc.es (A. Martínez-Abraín).
} 
country that has also experienced profound demographic changes during the last six decades. We suggest that the consequences of human depopulation of rural areas not only include the two major processes cited above but also the movement out of ecological refuges by previously shy-selected fauna, and increased frequencies of individuals with bolder personalities in animal populations (Geffroy et al., 2015; Martínez-Abraín et al., 2019a), leading to increased approach of wildlife to humanized areas. Therefore, we group several phenomena, that are usually overlooked or studied independently in the literature, into a single process. We also suggest a tentative conceptual framework linking human depopulation of rural areas with an increasing approach of wildlife to urban areas. Spain has more than 8000 municipalities distributed throughout a country of roughly $506,000 \mathrm{~km}^{2}$, with a population of approximately 47 million people. Human population density is 92 inhabitants $/ \mathrm{km}^{2}$, well under the European mean (177 inhabitants/ $\mathrm{km}^{2}$ ). Most Spaniards now live in large cities (51\%). The country is a major tourism destination (ca. 83 million visitors in 2019), with tourism mainly concentrated in coastal areas. Rural exodus started in the 1960s, and it is still an ongoing process. The start of this process was triggered on purpose in 1959, by means of the so-called "Stabilization Plan" to industrialize the country (Pérez-Pintos, 2009). Nowadays, a large part of the territory (ca. 50\%) is at risk of depopulation, when using the criterion of sparsely-populated areas, as defined by the European Union $\left(<12.5\right.$ inhabitants $/ \mathrm{km}^{2}$ ) (https://www.mptfp.gob.es/dam/es/portal/ reto_demografico/Indicadores_cartografia/Diagnostico_Despoblacion. pdf).

The historical impact of humans on wildlife, in Spain, can be thoroughly tracked back for several centuries. The middle Ages meant a period of great interaction between humans and wildlife due to the growth of a strong hunting tradition, as evidenced in books such as " $E l$ libro de la montería" (https://bibliotecadigital.jcyl.es/es/consulta/regist ro.cmd?id=16478), that was specifically devoted to big game hunting in, as early as, the 14th century. This led to the protection of some large wildlife species (both predators and prey), the hunting of which was reserved to the aristocracy. However, in Spain, the official persecution of some large mammalian carnivores by the crown, can be traced back to the 16th century. This was the case for grey wolves, that were officially persecuted since the reign of King Carlos I. Brown bears in the Cantabrian Mountains experienced an intense persecution from the 16th to the 19 th century. For example, 243 adult bears and 120 cubs were killed between 1751 and 1757, in Asturias alone (Torrente, 1999). Policies developed in the 19th and 20th centuries were especially harmful for wildlife. Approximately 15,000 wolves were culled in the period of 1855-1859 (Rico and Torrente, 2000). The extinction of many European brown bear populations (French Alps, Switzerland, Germany) also took place during this period. Persecution of the brown bear was continuous and intense in the French and Spanish Pyrenees during the final part of the 19 th century and first decades of the 20th century (Casanova, 2002). In 1953, the Spanish government began promoting the persecution of predators that could represent a possible check to small game species. This persecution led to the killing of ca. 16,000 small carnivorous mammals, 2000 wolves, 54,000 foxes, and 150 Iberian lynxes, as well as 550,000 birds (mostly raptors and corvids). This occurred across one fourth of the Spanish territory during the nine years following the governmental decision to sponsor the extirpation of vermin (Ministerio de Agricultura, 1962). This campaign did not include brown bears (that were intensively persecuted in previous centuries) because the species was already scarce and valued as a big game trophy. When this governmental campaign was about to succeed in its urge to extirpate the remaining major predators from the countryside, farmers moved to cities en masse. Modernity arrived in the country by 1970 and wildlife conservation began to change at a rapid pace. By that time, the first (hunting) laws protecting species threatened with extinction were developed, and the former wildlife extirpation councils were closed down. Furthermore, the year of 1970 marked the end of unrestrained predator control in the USA as well, according to Prugh et al. (2009).
From there on, international conventions and European directives took the lead regarding nature conservation, especially after Spain joined the European Union in 1986. The first law entirely devoted to nature conservation, rather than hunting, was finally developed in 1989, some 30 years ago.

\section{Ecological consequences of historical wildlife persecution in rural economies}

In order to fully understand the ecological consequences of human depopulation it is first necessary to briefly review the ecological consequences of intense wildlife persecution during the centuries in which rural activities were the rule (see Foster, 2009). The main ones were a) reduction of predator numbers and large ungulates, b) selection of individuals with shy personalities (i.e. selection of individuals afraid of humans, with low exploratory urge and low aggressiveness), c) seclusion of larger wildlife (vultures, large eagles, bears, wolves, lynxes) in remote areas acting as ecological refuges, and d) behavioural changes in diet (reduced carnivorism in omnivorous species), activity schedules (increased nocturnality), mating strategies (as a consequence of reduced densities) and even body size (reduction of size in large mammals) (Fernández-Gil et al., 2006; Oberosler et al., 2017; Gaynor et al., 2018). All features (genetically, epigenetically, and/or culturally acquired) that helped persecuted individuals remain hidden from humans were selected for via natural selection. In a way, human activity shaped wildlife to its needs, and this most likely affected species composition, abundance, distribution and behaviour. To summarise, centuries-old (or millennia old, depending on sites) agro-silvo-pastoral human activities moulded the structure of animal communities in southern Europe until the arrival of modernity, just a few decades ago (Diamond, 2012). To some extent, the rural activity of humans most likely acted as a functional substitute of the extinct mega-herbivore and mega-predator faunas of the Pleistocene times.

\section{Ecological consequences of the end of direct wildlife persecution by humans}

The massive movement of people to major cities (i.e. rural exodus) created vast areas with low human population density. Interestingly, the ecological effects of this depopulation did not become evident until recently (Salaverri et al., 2019), which suggests a non-linear response of the process, increasing the chances of rapid regime shifts (Hastings et al., 2018). Briefly, the ecological consequences of human depopulation, and the associated decrease in direct persecution of wildlife, can be grouped in four major points, with opposing results compared to those generated during centuries of intense human rural activity.

\subsection{Increased numbers of predators and large prey}

The end of the government-sponsored persecution of animal species considered as vermin, in 1970, most likely had a positive effect on the recovery of mammalian mesopredator numbers and range expansion. This would be expected according to the mesopredator release principle (see e.g. Crooks and Soulé, 1999; Prugh et al., 2009), although detailed quantitative trends for this animal group are lacking. In this case, the most relevant apex predator removed from the system were humans. In some Spanish agro-ecosystems, mesopredator abundance has been shown to be regulated more by top-down processes, such as prey availability, than bottom-up (Sobrino et al., 2009). The end of direct persecution also had a positive effect on some top mammalian predators. Wolf (Canis lupus) populations have grown and expanded geographically in NW Spain since the end of the 1980s (Blanco et al., 1990; Calmaestra et al., 2017), with an annual increase of ca $2 \%$ in its distribution area (Table 1, Fig. 1), despite the hunting and culling activities implemented during the last few decades by several regional governments. Only 50-60 brown bears (Ursus arctos) remained in the Cantabrian Mountains 
Table 1

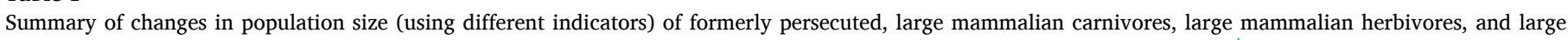

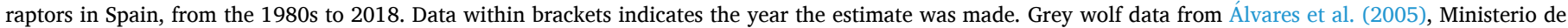

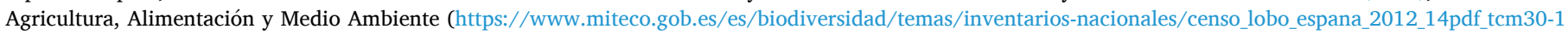

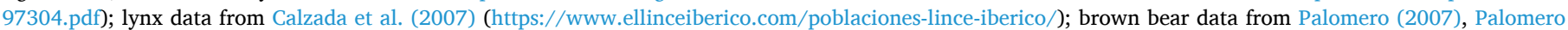

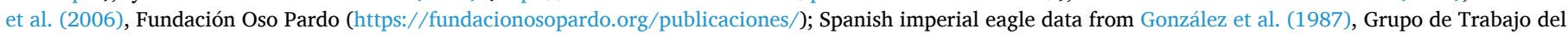

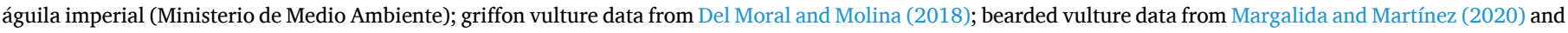

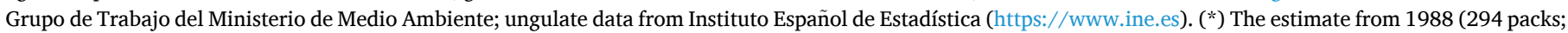

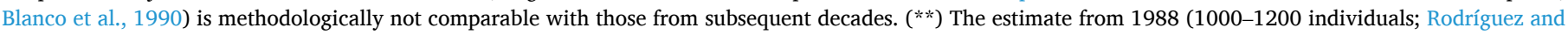
Delibes, 1990) was based on surveys and hence it is not comparable with those from subsequent decades.

\begin{tabular}{|c|c|c|c|c|c|}
\hline & Pop size unit & $1980 \mathrm{~s}$ & $1990 \mathrm{~s}$ & $2000 s$ & $2010 s$ \\
\hline \multicolumn{6}{|l|}{ Large carnivores } \\
\hline Grey wolf & Packs & * & & $\begin{array}{l}259 \\
(2000 / 2003)\end{array}$ & $\begin{array}{l}297 \\
(2014)\end{array}$ \\
\hline Brown bear (Cantabrian) & Females with cubs & $\begin{array}{l}6 \\
(1989)\end{array}$ & $\begin{array}{l}9 \\
(1995)\end{array}$ & $\begin{array}{l}15 \\
(2005)\end{array}$ & $\begin{array}{l}41 \\
(2017)\end{array}$ \\
\hline $\begin{array}{l}\text { Brown bear } \\
\text { (Pyrenees) }\end{array}$ & Individuals & & $\begin{array}{l}5 \\
(1995)\end{array}$ & & $\begin{array}{l}>50 \\
(2019)\end{array}$ \\
\hline Iberian lynx & Individuals $1+$ year & $* *$ & $450-700$ & $\begin{array}{l}94 \\
(2002)\end{array}$ & $\begin{array}{l}749 \\
(2019-2020)\end{array}$ \\
\hline \multicolumn{6}{|l|}{ Big game } \\
\hline Wild boar & Hunting bags & $\begin{array}{l}32,769 \\
(1985)\end{array}$ & $\begin{array}{l}75,060 \\
(1995)\end{array}$ & $\begin{array}{l}143,189 \\
(2005)\end{array}$ & $\begin{array}{l}310,280 \\
(2015)\end{array}$ \\
\hline Red deer & Hunting bags & $\begin{array}{l}19,993 \\
(1985)\end{array}$ & $\begin{array}{l}52,723 \\
(1995)\end{array}$ & $\begin{array}{l}78,449 \\
(2005)\end{array}$ & $\begin{array}{l}177,124 \\
(2015)\end{array}$ \\
\hline Roe deer & Hunting bags & & & $\begin{array}{l}14,073 \\
(2005)\end{array}$ & $\begin{array}{l}53,595 \\
(2015)\end{array}$ \\
\hline \multicolumn{6}{|l|}{ Large raptors } \\
\hline Spanish imperial eagle & Occupied territories & $\begin{array}{l}104 \\
(1985)\end{array}$ & $\begin{array}{l}148 \\
(1994)\end{array}$ & $\begin{array}{l}204 \\
(2005)\end{array}$ & $\begin{array}{l}520 \\
(2017)\end{array}$ \\
\hline Griffon vulture & Breeding pairs & $\begin{array}{l}7519 \\
(1989)\end{array}$ & $\begin{array}{l}17,337 \\
(1998)\end{array}$ & $\begin{array}{l}24,609 \\
(2008)\end{array}$ & $\begin{array}{l}30,945 \\
(2018)\end{array}$ \\
\hline Bearded vulture & Occupied territories & $\begin{array}{l}40 \\
(1986)\end{array}$ & $\begin{array}{l}63 \\
(1995)\end{array}$ & $\begin{array}{l}102 \\
(2005)\end{array}$ & $\begin{array}{l}126 \\
(2018)\end{array}$ \\
\hline
\end{tabular}

in 1982-1995, showing an annual estimated decrease of 4-5\% (Wiegand et al., 1998), whereas $>300$ are estimated today (Fundación Oso Pardo, 2020). Numbers of the Cantabrian bear continued to decrease after the hunting ban was issued in 1973 . However, numbers rebounded from the mid-1990s onwards without the implementation of any captivebreeding program, and have increased (i.e. females with cubs) at an annual rate of around 10\% since then (González et al., 2016; López-Bao et al., 2020). More specifically, the Cantabrian bear population increased from 6 females with cubs of the year detected in 1989, to 40 and 41 detected in 2016 and 2017, respectively (Planella et al., 2019) (Table 1). Their distribution range was broken into two isolated refuges in the Cantabrian Mountains since the XIX century. Cantabrian bears have not only expanded westward and southward, but have also achieved demographic and genetic exchange between the two formerly isolated nuclei (Pérez et al., 2010; González et al., 2016). By contrast, French and Spanish Pyrenean bears have been reinforced with the release of 11 Slovenian individuals in several batches (1996/97: 2 females and 1 male, 2006: 4 females and 1 male, 2016/18: 2 females and 1 male). Bear numbers in the Pyrenees have grown from ca. 5 individuals in 1995 (Casanova, 2002) to >50 in 2019 (Vanpé et al., 2019) (Table 1). The recovery of Iberian lynx (Lynx pardinus), however, has been dependant on continued and intense, ex-situ conservation policies and actions (see e.g. Bolam et al., 2020). While only 94 individuals remained in 2002, 700 individuals were estimated in 2019 (Table 1), although this recovery required the release of ca. 250 individuals since 2011 (Iberlince, 2018). Remarkable increases have also been reported for large, obligate, tree-nesting eagles (see Martínez-Abraín et al., 2020), such as the Spanish imperial eagle (Aquila adalberti), which increased from ca. 100 pairs in the 1980s (Ferrer, 2001) (Table 1) to 520 nesting pairs in 2017 (Ministerio para la Transición Ecológica, 2018). The population multiplied by 5 in 30 years.

Additionally, not only have predators increased in numbers but big game ungulates, that were hunted intensively in the past, are now thriving (Table 1), such as wild boars (Sus scrofa), red deer (Cervus elaphus), and roe deer (Capreolus capreolus). The increase in ungulate biomass has, in turn, contributed to the recovery of obligate scavengers, such as vultures (Martín-Díaz et al., 2020), along with the additional help of conservation policies, such as supplementary feeding (Margalida et al., 2020), and through the banning of the use of poison. For example, griffon vultures have multiplied their population by a factor of 10 in 40 years (from 3240 pairs in 1979 to $31-37,000$ pairs in 2018), and have expanded their range accordingly (Fig. 1, Table 1).

\subsection{Movement out of ecological refuges to unprotected sites}

Many animal populations that were formerly secluded in remote areas with little human disturbance (ecological refuges) are leaving those suboptimal habitats (now legally protected as nature or national parks) at an increasing rate. They are progressively re-colonizing other habitats due to the lack of direct human persecution associated to the human depopulation of rural areas (Morandini et al., 2017; Silliman et al., 2018; Martínez-Abraín et al., 2019a). The reduction in direct human persecution does not entail a complete absence of threats to wildlife. Most impacts are now caused indirectly via the development of the communication and energy supply infrastructure (Martínez-Abraín et al., 2009, 2013), but wildlife does not perceive that additive mortality such as direct predation by humans. The process of "refuge abandonment" will most likely force the development of new conservation policies (Martínez-Abraín et al., 2019b), and will increase the demand for improved maps of habitat suitability in relation to currently "empty" sites (Bonnet-LeBrun et al., 2019). This means that many presently unused, high-quality sites will become occupied in the future, as currently occupied sites are abandoned. Importantly, this process of refuge abandonment often implies that individuals from legally protected sites move to unprotected areas, showing the suboptimal nature of former refuges. This is, for example, the case of the Egyptian vulture (Cortés- 

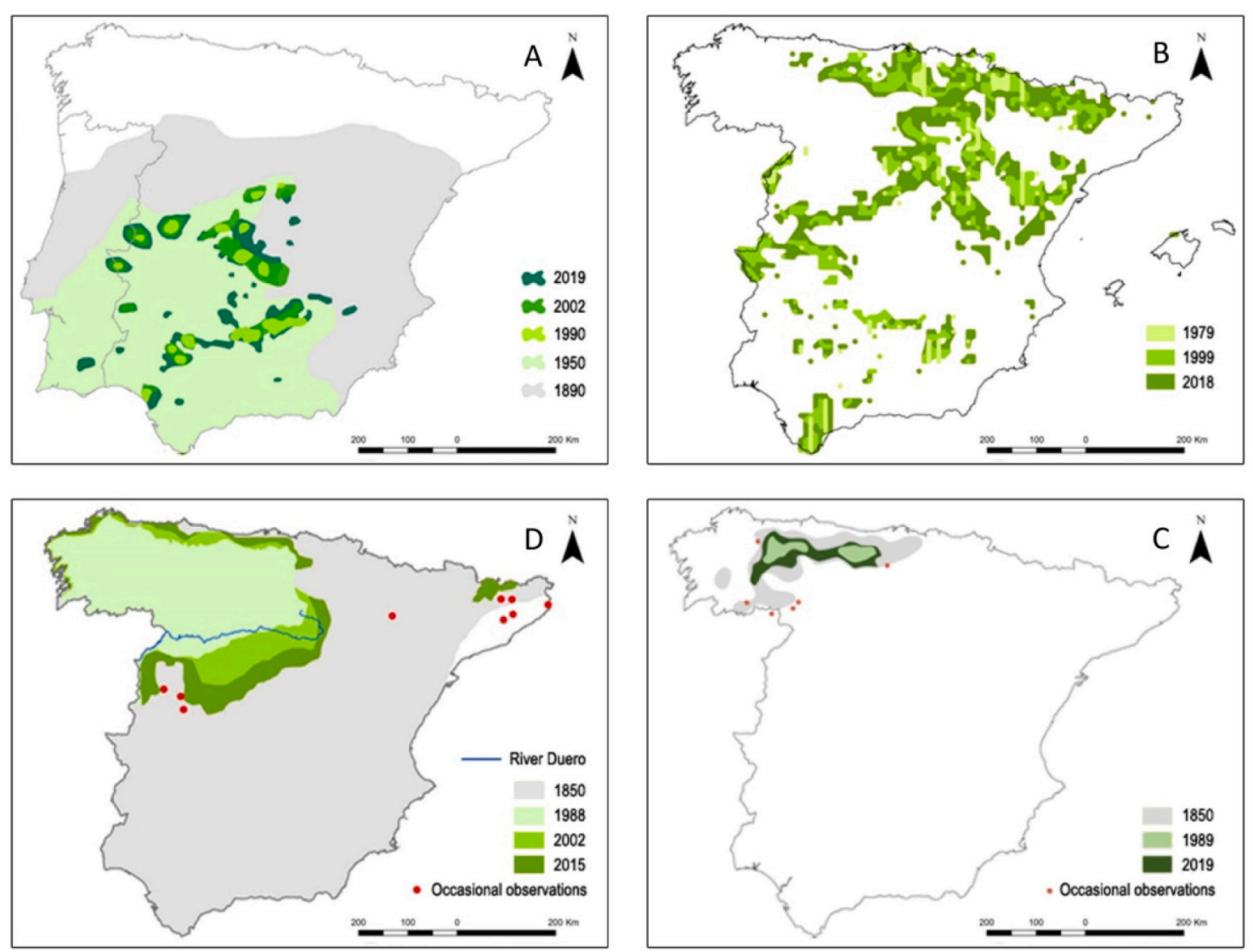

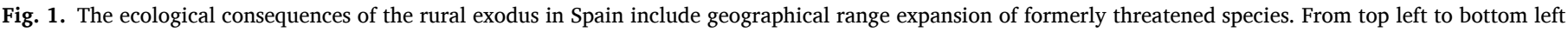

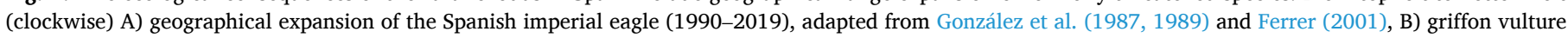

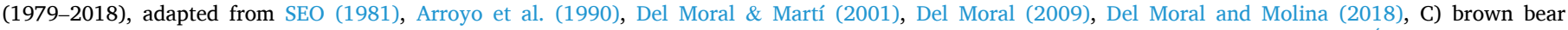

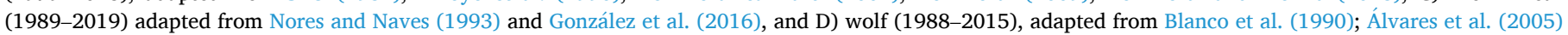
and Sáenz de Buruaga et al. (2018).

Avizanda et al., 2015) and the Spanish imperial eagle, with some pairs of the latter moving to pine plantations that are under human exploitation where they are paradoxically increasing at a faster rate than in protected areas (Rojo et al., 2013; Morandini et al., 2017). In both cases, birds move to places where abundance of their main food resource, dead or alive wild rabbits (Oryctolagus cuniculus) respectively, is higher than in protected areas, where cropland abandonment has promoted shrub and tree encroachment. Even the Iberian lynx (whose staple food is also rabbits) is becoming scarcer in protected areas, where traditional management (i.e. clearcutting and prescribed burning) was banned by conservation policies (Moreno and Villafuerte, 1995), as rabbit densities are much higher in intensively managed hunting estates (e.g. olive groves) (Delibes-Mateos et al., 2009). After a successful captivebreeding programme, Iberian lynx have begun to colonize and breed in intensive olive tree plantations (Garrote et al., 2017), a habitat considered in the 20th century as worse than holm oak (Quercus ilex) forests, but that can support higher densities of rabbits (and even higher lynx female fecundities) than natural habitats (Garrote et al., 2020). Hence, the absence of lynx in olive groves could be more closely related to a higher rate of human-induced mortality than to a lack of resources (i.e. prey and shelter).

The movement (either complete or partial) of wildlife out of refuges is teaching us valuable lessons regarding true animal preferences. We are witnessing how animal species that were thought to be selecting habitats based on preference were actually doing so through human avoidance. They are now getting out of their forced refuges and are selecting habitats that were not thought to be suitable or optimal. For example, species traditionally considered in the past to have preference for the upper stretches of rivers with pristine waters, such as Eurasian otters (Lutra lutra), are now present outside these areas and along the whole course of rivers (including many major city centres; Fig. 2) and make use of beaches, harbours, reservoirs and all sorts of small ponds in urbanized areas where they can find food, often exotic species (Pedroso et al., 2007; Martínez-Abraín and Jiménez, 2016). In fact, Ruiz-Olmo et al. (2011) already found that otter breeding success correlates negatively with altitude, that is, with remoteness. Large cliff-nesting raptors are rapidly increasing the percentage of pairs breeding in trees, a more vulnerable nesting substrate as it is more accessible to humans (Martínez-Abraín and Jiménez, 2019a; Martínez-Abraín et al., 2020). For example, the percentage of Bonelli's eagles nesting in trees in Spain, in 1990 , was $1.8 \%(n=679)$, whereas, it increased to $4.6 \%$ in 2005 ( $n=733$ ) (Del Moral, 2006), and to 7.5\% in $2018(n=709)$ (Del Moral and Molina, 2018b). Golden eagles are deserting territories at high altitudes (despite global warming) and increasing their numbers at lower altitudes, where human densities are higher (Martínez-Abraín et al., 2019a).

\subsection{Increased frequency of individuals with bolder personalities and in their approach to urban areas}

Wildlife in the process of leaving historical refuges is also losing fear to humans (Ferrer et al., 1990; Arroyo et al., 2017). Many species can now be spotted at shorter distances and in broad daylight. Nocturnality is known to decrease in mammals when human disturbance decreases (Martínez-Abraín and Oro, 2018). New ecological opportunities arise for individuals with bold (fearless) behaviours, compared to secretive, shy- 

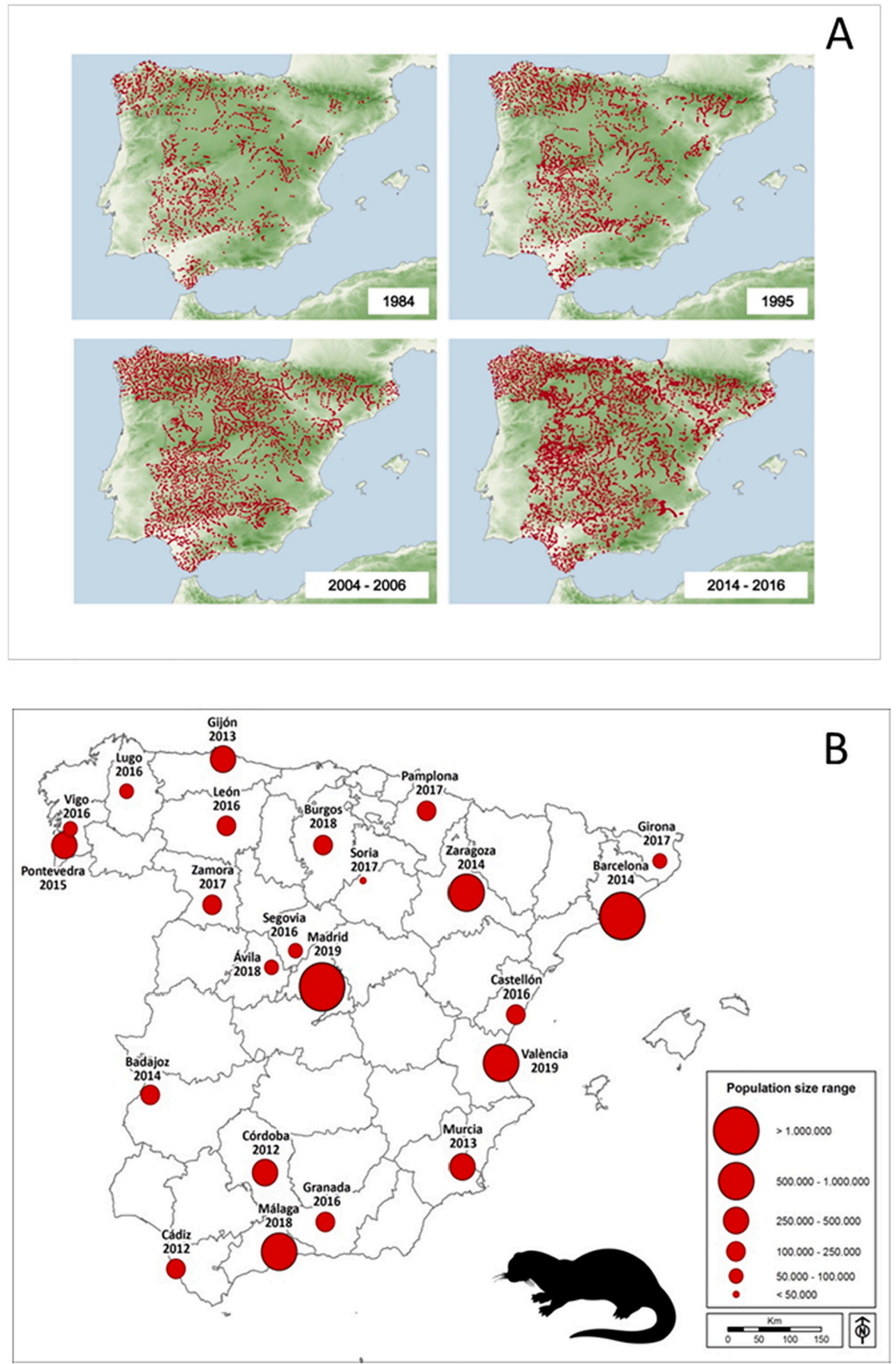

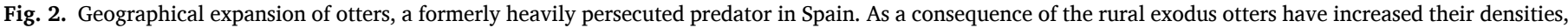

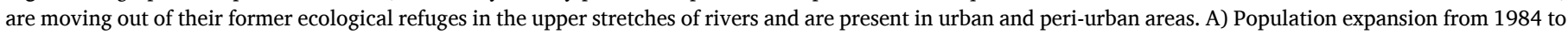

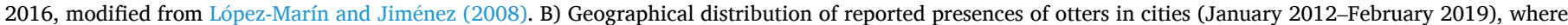

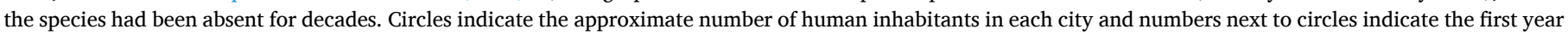
in which otter presence was reported. 
selected individuals that remain in their refuges (Martínez-Abraín, 2018). Many animal species are colonizing or are becoming more frequent in urban environments, and loss of fear to humans correlates with urban wildlife (Riyahi et al., 2015; Geffroy et al., 2015, 2020). For example, in the city of Barcelona, currently, two of the five most abundant urban bird species did not colonize the city until 1989 or later (Anton et al., 2017; and XF own unpublished data). One of which, the native wood pigeon (Columba palumbus), intensively persecuted by hunting in the past, has built an urban population of several thousand breeding pairs in just two decades since first colonization (Anton et al., 2017). In addition, the rebound of mesopredators in human depopulated areas, together with changed human attitudes and the large amounts of available food that is a by-product of human activities (Oro et al., 2013), could also be causing the increasing approach of wildlife to urban areas (Rebolo-Ifrán et al., 2015) (see a tentative conceptual model summarizing this process in Fig. 3). It is to be expected that predators will follow the same path as their prey in the future. For example, red kites (Milvus milvus) are already colonizing urban areas on the island of Majorca (Muntaner, 2019), and common kestrels (Falco tinnunculus) and peregrine falcons ( $F$. peregrinus), among other diurnal and nocturnal raptor species, are increasingly common in many cities, mainly large ones (Murgui and Hedblom, 2017).

The spread of bolder behaviours and the approach of wildlife to urban areas is also bringing new challenges for human-wildlife coexistence. For example, cases of wild boar and roe deer causing road accidents have increased exponentially (Lagos et al., 2012). The expansion of wolves to areas where livestock damage prevention measures were ceased long ago, following the extirpation of these species, are giving rise to social conflicts that require awareness efforts and the provision of preventive measures for conflict mitigation (Fernández-Gil et al., 2016; Martínez-Abraín et al., 2019b; Salvatori et al., 2020). Cantabrian bears seem to be shy-selected bears (based on the low number of attacks to people and livestock recorded; see e.g. Casanova, 2002). In the last 30 years only seven attacks on humans have been recorded in the Cantabrian Mountains, none with serious consequences (Blanco et al., 2020). However, events of bolder bears foraging in or near urbanized areas in the Cantabrian Mountains are starting to become more common. This is a natural consequence of low local population densities, together with a high abundance of fruit, and bear despotic behaviour (Elfström et al., 2014). These cases can lead to dangerous situations (especially due to the increased presence of people in the countryside for recreational purposes) or become ecological traps if attractive human areas increase mortality in the long run (Lamb et al., 2017). In consequence, efforts are needed to prevent the availability of attractive food resources near villages and to implement bear aversive conditioning, to preserve the shy nature of Cantabrian bears.

\subsection{Forest spread: positive and negative effects on wildlife}

The widespread depopulation of rural areas has led to shrub and tree encroachment on former cropland. Moreover, expanding forests are now more dense than they used to be (Ameztegui et al., 2010) because human extraction of plant biomass and wild-ranging livestock no longer takes place. One of the by-products of vegetation succession on wildlife is the reduction of open areas. This process is responsible for the increasing populations of forest bird species and large mammalian ungulates (red deer Cervus elaphus, roe deer, wild boar) (Acevedo et al., 2011), as well as the decreasing trends of formerly common birds (Preiss et al., 1997; SEO/BirdLife doi:10.31170/0073; Inger et al., 2014) dependent on open farmland. Some bird species can experience opposing forces as forest expansion increases nesting substrate, while shrub and tree encroachment causes open feeding areas to shrink. This is

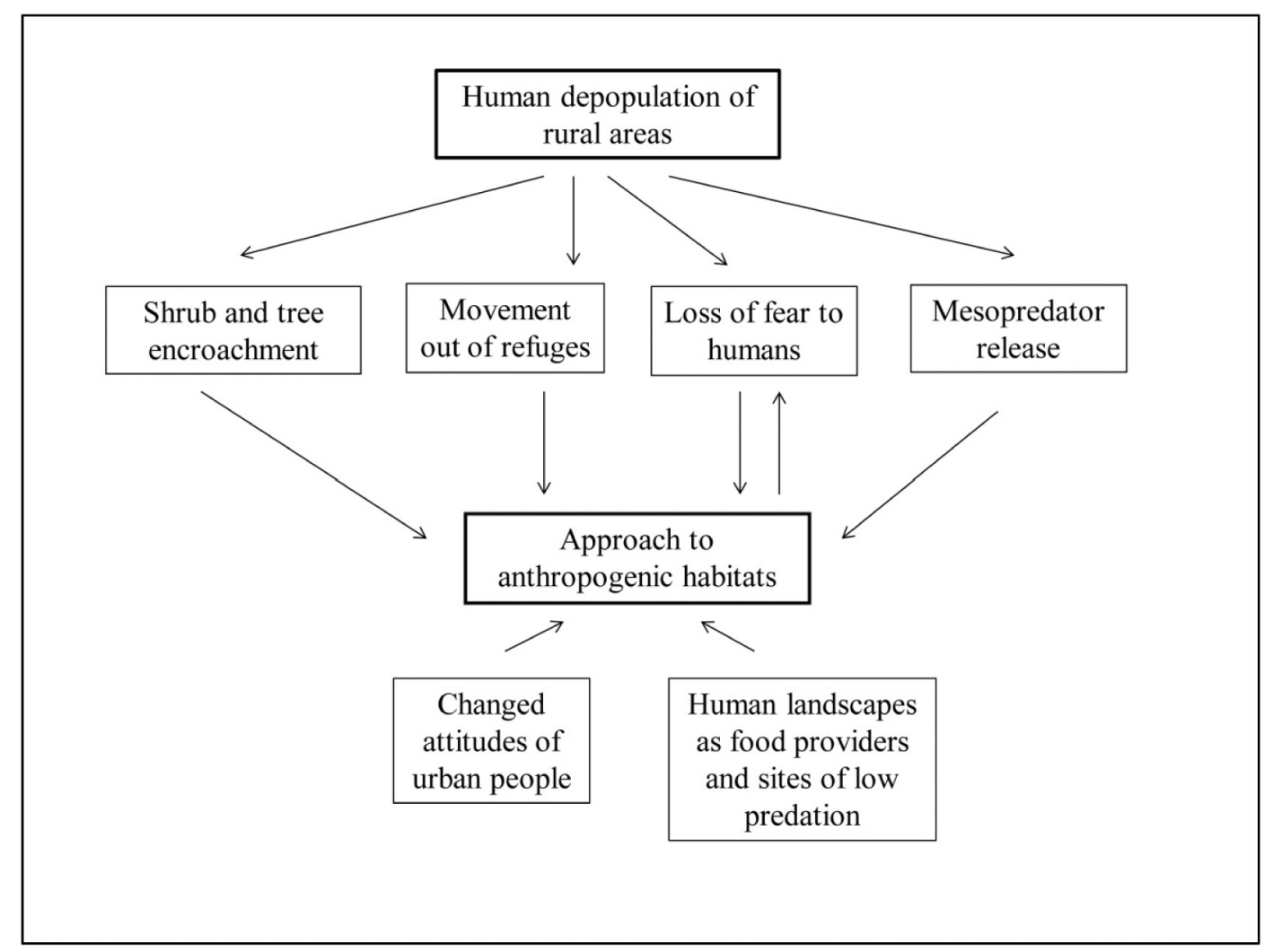

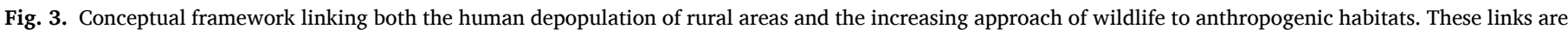

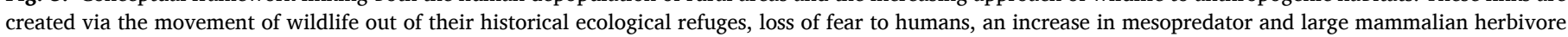

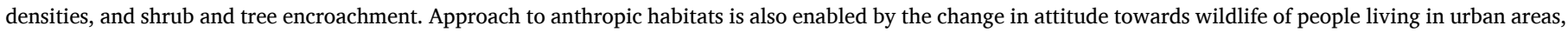
and is fostered by the services these habitats provide as sources of food and as sites of low predation. 
the case for the cinereous vulture (Aegypius monachus), an obligate treenester that scavenges in open land (García-Barón et al., 2018). Cropland abandonment and changes in pasture use in mountainous areas are also seen as threats for some small mammal species, such as the Cantabrian endemic broom hare (Lepus castroviejoi), due to loss of landscape diversity (Ballesteros, 2018). Shrub and tree encroachment has also negatively affected many amphibian and reptile species. This is because ectothermic species are sensitive to changes in vegetation density, which is linked to human depopulation of rural areas, although, this topic has not been extensively studied to date. Amphibians and reptiles with low vagility are particularly influenced by the abandonment of farming and livestock growing (Cushman, 2006). In northern Spain, scrubland expansion in abandoned croplands negatively affects various reptile species, such as the Iberian green lizard (Lacerta schreiberi) and Seoane's viper (Vipera seoanei), as well as some amphibians such as the goldenstriped salamander (Chioglossa lusitanica) and common frogs (Rana temporaria) (Galán, 1999; Martínez-Abraín and Galán, 2017). Amphibians are also negatively affected by the widespread reliance of many populations on the existence of ponds for reproduction in agricultural areas, many of which disappear when traditional agricultural and livestock practices are discontinued (Curado et al., 2011). As a general rule, butterfly species from open habitats are also becoming rare, whereas, numbers of formerly rare butterfly species are rising (Stefanescu et al., 2004, 2009). As a rule, insect biomass is declining in Europe (75\% decline in 27 years) (Hallmann et al., 2017; but see Herrera, 2018, 2019, for trends in mountain areas in southern Europe), yet herbivorous forest insects are expanding and forest insect plagues are now reaching the highest levels recorded since monitoring programs began (de la Fuente et al., 2018). Some authors have recently suggested that the rate of growth of forest insectivorous passerines, in Europe, cannot cope with the rate of growth of forest insects associated with the spreading of young forest masses (Martínez-Abraín and Jiménez, 2019b). Future management should promote the persistence of forest/pasture mosaics for the maximization of biodiversity (Bennet et al., 2006; Martín-Díaz et al., 2020), promoting the use of livestock and prescribed fires (San Miguel-Ayanz et al., 2010).

\section{Concluding remarks}

The ecological consequences of human depopulation of rural areas, and the associated abandonment of croplands in southern Europe several decades ago, are more diverse than previously thought, according to our unifying or integrative perspective. In order to fully understand the current structure of animal communities it is necessary to take into account all of the following: past wildlife persecution under subsistence rural economies, the seclusion of wildlife in ecological refuges, the selection of individuals with shier personalities, and the subsequent (opposite direction) changes after human depopulation of rural areas took place. These processes that we have reviewed for Spain will most likely take place in other countries that are in a similar socioeconomic state to that of Spain,60-70 years ago. This situation applies to other southern European countries (such as Portugal or Greece), countries in Latin America (such as Costa Rica as well as some regions in Mexico), several regions of Asia (Thailand, Malaysia, Indonesia), and some growing African economies such as Kenya (Loock et al., 2018). It can even be relevant for some western states of the United States of North America in which the demographic transition took place relatively late (Hansen et al., 2002). Importantly, the process that we have considered on a national scale might be occurring in Europe on a continental scale as well. The eastern, south-eastern and central European human rural populations are rapidly shrinking, whereas, the industrialized western European human population is growing (United Nations Populations Prospects; https://population.un.org/wpp/). This process may lead to further recovery of wildlife in Western Europe with propagules coming from increasingly depopulated and naturally rewilded rural parts of Central and Eastern Europe. In fact, wolves have already recolonized Germany (year 2000), the Netherlands (year 2015), Denmark (year 2017) and Belgium (year 2018), and most European bear and wolf populations are experiencing increasing or stable trends (Chapron et al., 2014). The influence of this continent-wide process may become more evident in the decades to come. Population recovery of formerly persecuted wildlife species resulted necessarily from the additive effect of proper policy regulations and the favourable conditions for conservation created by human depopulation. However, to some extent, the process of policy development for wildlife conservation could also be seen as an indirect consequence of the human depopulation of rural areas, as urban people in industrialized cities changed their attitudes towards wildlife and ceased perceiving wildlife as competitors or enemies. Finally, we have suggested that the increasing use of anthropogenic habitats by wildlife could be the result of the role that humanized areas play in providing areas of low-predation and high food abundance, the increasing difficulty to survive and reproduce in recovering wild habitats with high-predation, and through the loss of fear to humans. Further research should test the validity of this tentative model and its potential to be generalized.

\section{Declaration of competing interest}

The authors have no conflict of interests to declare.

\section{Acknowledgments}

We are grateful to S. Palazón (SECEM) for the advanced information on the 4th Spanish otter survey, and to C. Andrés who helped us build Fig. 2. We are also grateful to M. Delibes de Castro for providing literature on olive grove use by Iberian Lynx and to Rubén Moreno-Opo for providing historical counts of bearded vultures and Spanish imperial eagle. AMA received funding from Xunta de Galicia (Programa de Investigación Competitiva del Sistema Universitario Gallego, ED431C 2018/57). XF thanks the financial support of Fundació Barcelona Zoo and Ajuntament de Barcelona and MINUARTIA Estudis Ambientals.

\section{References}

Acevedo, P., Farfán, M.A., Márquez, A.L., Delibes-Mateos, M., Real, R., Vargas, J.M., 2011. Past, present and future of wild ungulates in relation to changes in land use. Landsc. Ecol. 26, 19-31.

Álvares, F., Barroso, I., Blanco, J.C., Correia, J., Cortés, Y., Costa, G., Llaneza, L., Moreira, L., Nascimento, J., Palacios, V., Petrucci-Fonseca, F., 2005. Wolf Status and Conservation in the Iberian Peninsula, Frontiers of Wolf Recovery: Southwestern US and the World (IWC) (Colorado Spring).

Ameztegui, A., Brotons, L., Coll, L., 2010. Land-use changes as major drivers of mountain pine (Pinus uncinata Ram.) expansion in the Pyrenees. Global Ecol. Biogeogr. 19, 632-641.

Anton, M., Herrando, S., García, D., Ferrer, X., Cebrian, R., 2017. Atles dels ocells nidificants de Barcelona. Ajuntament de Barcelona/ICO/Universitat de Barcelona/ ZOO, Barcelona.

Arroyo, B., Ferreiro, E., Garza, V., 1990. II censo nacional del buitre leonado (Gyps fulvus): población, distribución, demografía y conservación. ICONA, Madrid.

Arroyo, B., Mougeot, F., Bretagnolle, V., 2017. Individual variation in behavioural responsiveness to humans leads to differences in breeding success and long-term population phenotypic changes. Ecol. Lett. 20, 317-325.

Ballesteros, F. 2018. Lepus castroviejoi, in: Smith, A.T., Johnston, C.H., Alves, P.C. Hackländer, K. (Eds.), Lagomorphs: Pikas, Rabbits, and Hares of the World, John Hopkins University Press, pp. 179-180.

Bennet, A.F., Radford, J.Q., Haslem, A., 2006. Properties of land mosaics: implications for nature conservation in agricultural environments. Biol. Conserv. 133, 250-264.

Blanco, J.C., Cuesta, L., Reig, S., 1990. El lobo (Canis lupus) en España. In: Situación, problemática y apuntes sobe su ecología. ICONA, Madrid.

Blanco, J.C., Palomero, G., López-Bao, J.V., Ballesteros, F., 2020. Geographical concentration of attacks on humans in an endangered population of brown bears (Ursus arctos). Oryx (in press).

Blondel, J., Aronson, J., 1999. Biology and Wildlife of the Mediterranean. Oxford University Press, Oxford.

Bolam, F.C., et al., 2020. How many bird and mammal extinctions has recent conservation action prevented? Conservation Letters: e12762.

Bonnet-LeBrun, A.S., Karamanlidis, A.A., de Gabriel Hernando, M., Renner, I., Giménez, O., 2019. Identifying priority conservation areas for a recovering brown bear population in Greece using citizen science data. Anim. Conserv. 23, 83-93. 
Calmaestra, R.G., Muñoz, J., García, F. 2017. Líneas de trabajo del Ministerio de Agricultura y Pesca, Alimentación y Medio Ambiente (MAPAMA) en relación al lobo en España: coordinación del censo nacional 2012-2014 y evaluación de nuevas técnicas de protección del ganado, in: Sáenz de Buruaga M. \& Llaneza L. (Eds.), Segundo Seminario sobre el Lobo (Canis lupus) en el Parque Nacional de los Picos de Europa: veinte años después, SECEM - Consorcio Interautonómico PNPE, Málaga, pp 67-80.

Calzada, J., Guzmán, N., Rodríguez, A., 2007. Lynx pardinus, Ficha Libro Rojo. In: Palomo, L.J., Gisbert, J., Blanco, J.C. (Eds.), Atlas y Libro Rojo de los Mamíferos Terrestres de España. Dirección General para la Biodiversidad-SECEM-SECEMU, Madrid, pp. 345-347.

Casanova, E., 2002. Crónica de un exterminio: el oso de los Pirineos (Editorial Milenio).

Chapron, G., Kaczensky, P., Linnell, J.D.C., von Arx, M., Huber, D., Andrén, H., LópezBao, J.V., Adamec, M., Álvares, F., Anders, O., Balčiauskas, L., Balys, V., Bedő, P., Bego, F., Blanco, J.C., Breitenmoser, U., Brøseth, H., Bufka, L., Bunikyte, R., Ciucci, P., Dutsov, A., Engleder, T., Fuxjäger, C., Groff, C., Holmala, K., Hoxha, B., $€$ Iliopoulos, Y., Ionescu, O., Jeremić, J., Jerina, K., Kluth, G., Knauer, F., Kojola, I., Kos, I., Krofel, M., Kubala, J., Kunovac, S., Kusak, J., Kutal, M., Liberg, O., Majić, A., Männil, P., Manz, R., Marboutin, E., Marucco, F., Melovski, D., Mersini, K., Mertzanis, Y., Mysłajek, R.W., Nowak, S., Odden, J., Ozolins, J., Palomero, G., Paunović, M., Persson, J., Potočnik, H., Quenette, P.-Y., Rauer, G., Reinhardt, I., Rigg, R., Ryser, A., Salvatori, V., Skrbinšek, T., Stojanov, A., Swenson, J.E., Szemethy, L., Trajçe, A., Tsingarska-Sedefcheva, E., Váňa, M., Veeroja, R., Wabakken, P., Wölfl, M., Wöfl, S., Zimmermann, F., Zlatanova, D., Boitani, L. 2014. Recovery of large carnivores in Europe's modern human-dominated landscapes. Science, 346: 1517-1519.

Cortés-Avizanda, A., Colomer, M.A., Margalida, A., Ceballos, O., Donázar, J.A., 2015. Modelling the consequences of the demise and potential recovery of a key-stone species: wild rabbits and avian scavengers in Mediterranean landscapes. Sci. Rep. 5, 17033.

Crooks, K.R., Soulé, M.E., 1999. Mesopredator release and avifaunal extinctions in a fragmented system. Nature 400, 563-566.

Curado, N., Hartel, T., Arntzen, J.W., 2011. Amphibian pond loss as a function of landscape change: a case study over three decades in an agricultural area of northern France. Biol. Conserv. 144, 1610-1618.

Cushman, S.A., 2006. Effects of habitat loss and fragmentation on amphibians: a review and prospectus. Biol. Conserv. 128, 231-240.

de la Fuente, B., Saura, S., Beck, P.S.A., 2018. Predicting the spread of an invasive tree pest: the pine wood nematode in southern Europe. J. Appl. Ecol. 55, 2374-2385.

Debussche, M., Lepart, J., Dervieux, A., 1999. Mediterranean landscape changes: evidence from old postcards. Glob. Ecol. Biogeogr. 8, 3-15.

Del Moral, J.C. (Ed.), 2006. El águila perdicera en España. Población en 2005 y método de censo. SEO/BirdLife, Madrid.

Del Moral, J.C. (Ed.), 2009. El buitre leonado en España. Población reproductora en 2008 y método de censo. SEO/BirdLife, Madrid.

Del Moral, J.C., Martí, R. (Eds.), 2001. El buitre leonado en la Península Ibérica. III Censo Nacional y I Censo Ibérico coordinado, 1999. Monografía nº 7. SEO/BirdLife, Madrid.

Del Moral, J.C., Molina, B. (Eds.), 2018a. El buitre leonado en España, población reproductora en 2018 y método de censo. SEO/BirdLife, Madrid.

Del Moral, J.C., Molina, B. (Eds.), 2018b. El águila perdicera en España, población reproductora en 2018 y método de censo. SEO/BirdLife, Madrid.

Delibes-Mateos, M., Ferreras, P., Villafuerte, R., 2009. Rabbit (Oryctolagus cuniculus) abundance and protected areas in central-southern Spain: why they do not match? Eur. J. Wildl. Res. 55, 65.

Diamond, J., 2012. The World Until Yesterday: What Can we Learn From Traditional Societies? Penguin Books.

Elfström, M., Zedrosser, A., Jerina, K., Støen, O.G., Kindberg, J., Budic, L., Swenson, J.E. 2014. Does despotic behavior or food search explain the occurrence of problem brown bears in Europe? J. Wildlife Manage. 78, 881-893.

Falcucci, A., Maiorano, L., Boitani, L., 2007. Changes in land use/land cover patterns in Italy and their implications for biodiversity conservation. Landsc. Ecol. 22, 617-631.

Farina, A., 1991. Recent changes of the mosaic patterns in a montane landscape (north Italy) and consequences on vertebrate fauna. Options Mediterr. 15, 121-134.

Farina, A., 1997. Landscape structure and breeding bird distribution in a subMediterranean agro-ecosystem. Landsc. Ecol. 12, 365-378.

Fernández-Gil, A., Naves, J., Delibes, M., 2006. Courtship of brown bears Ursus arctos in northern Spain: phenology, weather, habitat and durable mating areas. Wildlife Biol. $12,367-373$.

Fernández-Gil, A., Naves, J., Ordiz, A., Quevedo, M., Revilla, E., Delibes, M., 2016. Conflict misleads large carnivore management and conservation: brown bears and wolves in Spain. PLoS One 11, e0151541.

Ferrer, M., 2001. The Spanish Imperial Eagle. Editorial Lynx, Barcelona.

Ferrer, M., García, L., Cadenas, R., 1990. Long-term changes in nest defense intensity of the Spanish imperial eagle, Aquila adalberti. Ardea 78, 395-398.

Foster, H., 2009. The importance of land-use legacies to ecology and conservation. BioScience 53, 77-88.

Fundación Oso Pardo. 2020. The number of bears and where they live [WWW Document]. URL https://fundacionosopardo.org/wp-content/uploads/2020/07/fich a1-julio2020_ing1\%C3\%A9s.pdf (last accesed 10.08.20).

Galán, P. 1999. Conservación de la herpetofauna gallega. Situación actual de los anfibios y reptiles de Galicia. Universidade da Coruña. Servicio de Publicacións. Monografía $\mathrm{N}^{\circ} 72$, A Coruña.

García-Barón, I., Cortés-Avizanda, A., Verburd, P.H., Marques, T.A., Moreno-Opo, R., Pereira, H.M., Donázar, J.A., 2018. How to fit the distribution of apex scavengers into land-abandonment scenarios? The cinereous vulture in the Mediterranean biome. Divers. Distrib. 24, 1018-1031.

García-Ruiz, J.M., Lasanta, T., Ruiz-Flano, P., Ortigosa, L., White, S., Gonzàles, C., Martí, C., 1996. Land-use changes and sustainable development in mountain areas: a case study in the Spanish Pyrenees. Landsc. Ecol. 11, 267-277.

Garrote, G., López, G., Bueno, J.F., Ruiz, M., de Lillo, S., Simón, M.A., 2017. Iberian lynx (Lynx pardinus) breeding in olive tree plantations. Mammalia 81, 405-409.

Garrote, G., Bueno, J.F., Ruiz, M., de Lillo, S., Martin, J.M., Moral, M., Simón, M.A., 2020. Breaking barriers: Iberian Lynx Lynx pardinus Temminck, 1827 (Mammalia: Carnivora: Felidae) colonizing olive groves. J. Threat. Taxa 12, 15221-15228.

Gaynor, K.M., Hojnowski, C.E., Carter, N.H., Brashares, J.S., 2018. The influence of human disturbance on wildlife nocturnality. Science 360, 1232-1235.

Geffroy, B., Samia, D.S.M., Bessa, E., Blumstein, D.T., 2015. How nature-based tourism might increase prey vulnerability to predators. Trends Ecol. Evol. 30, 755-765.

Geffroy, B., Sadoul, B., Putman, B.J., Berger-Tal, O., Garamszegi, L.Z., Pape Møller, A., Blumstein, D.T. 2020. Evolutionary dynamics in the Anthropocene: life history and intensity of human contact shape antipredator responses. PLoS Biology (doi:https ://doi.org/10.1371/journal.pbio.3000818).

González, L.M., González, J.L., Garzón, J., Heredia, B., 1987. Censo y distribución del águila imperial Ibérica Aquila adalberti en España durante el periodo 1981-1986. Boletín de la Estación Central de Ecología 31, 99-109.

González, L.M., Hiraldo, F., Delibes, M., Calderón, J., 1989. Reduction in the range of Spanish Imperial Eagle Aquila adalberti since 1850. J. Biogeogr. 16, 305-331.

González, E.G., Blanco, J.C., Ballesteros, F., Alcaraz, L., Palomero, G., Doadrio, I. 2016. Genetic and demographic recovery of an isolated population of brown bear Ursus arctos L., 1758. PeerJ, 2016, 4: e1928.

Hallmann, C.A., Sorg, M., Jongejans, E., Siepel, H., Hofland, N., Schwan, H., Stenmans, W., Müller, A., Sumser, H., Hörren, T., Goulson, D., de Kroon, H., 2017. More than 75\% decline over 27 years in total flying insect biomass in protected areas. PLoS One 12, e0185809.

Hansen, A.J., Rasker, R., Maxwell, B., Rotella, J.J., Johnson, J.D., Wright Parmenter, A., Langner, U., Cohen, W.B., Lawrence, R.L., Kraska, M.P.V., 2002. Ecological causes and consequences of demographic change in the new west. BioScience 52, 151-162.

Hastings, A., Abbott, K.C., Cuddington, K., Francis, T., Gellner, G., Lai, A., Morozov, Y-C., Petrovskii, S., Scranton, K., Zeeman, M.L. 2018. Transient phenomena in ecology. Science. 361: eaat6412.

Herrera, C.M., 2018. Complex long-term dynamics of pollinator abundance in undisturbed Mediterranean montane habitats over two decades. Ecol. Monogr. 89, e01338.

Herrera, C.M., 2019. Increasing pollinator abundance in undisturbed Mediterranean montane habitats over recent decades. Ecol. Monogr. 100, e01480.

Iberlince. 2018. Layman report. Junta de Andalucía (http://www.iberlince.eu/images/ docs/layman_eng.pdf) (last accessed 29.09.20).

Inger, R., Gregory, R., Duffy, J.P., Stott, I., Voříšek, P., Gaston, K.J., 2014. Common European birds are declining rapidly while less abundant species' numbers are rising. Ecol. Lett. 18, 28-36.

Lagos, L., Picos, J., Valero, E., 2012. Temporal pattern of wild ungulate-related traffic accidents in northwest Spain. Eur. J. Wildlife Res. 58, 661-668.

Lamb, C.T., Mowat, G., McLellan, B.N., Nielsen, S.E., Boutin, S., 2017. Forbidden fruit: human settlement and abundant fruit create an ecological trap for an apex omnivore. J. Anim. Ecol. 86, 55-65.

Loock, D.J.E., Williams, S.T., Emslie, K.W., Matthews, W.S., Swanepoel, L.H., 2018. High carnivore population density highlights the conservation value of industrialised sites. Sci. Rep. 8, 16575.

López-Bao, J.V., Godinho, R., Rocha, R.G., Palomero, G., Blanco, J.C., Ballesteros, F., Jiménez, J., 2020. Consistent bear population DNA-based estimates regardless molecular markers type. Biol. Conserv. 248, 108651.

López-Marín, J.M., Jiménez, J. (Eds.), 2008. La nutria en España: veinte años de seguimiento de un mamífero amenazado. Spanish Society for the Conservation and Study of Mammals SECEM, Málaga.

MacDonald, D., Crabtree, J.R., Wiesinger, G., Dax, T., Stamou, N., Fleury, P., Gutierrex Lazpita, J., Gibon, A., 2000. Agriculture abandonment in mountain areas of Europe: environmental consequences and policy response. J. Environ. Manag. 59, 47-69.

El quebrantahuesos en España, población reproductora en 2018 y método de censo. In: Margalida, A., Martínez, J.M. (Eds.), 2020. Instituto de Investigación en Recursos Cinegéticos (CSIC-UCLM-JCCM). Real, Ciudad.

Margalida, A., Jiménez, J., Martínez, J.M., Sesé, J.A., García-Ferré, D., Llamas, A., Razin, M., Colomer, M.A., Arroyo, B., 2020. An assessment of population size and demographic drivers of bearded vulture using integrated population models. Ecol. Monogr. https://doi.org/10.1002/ecm.1414.

Martín-Díaz, P., Cortés-Avizanda, A., Serrano, D., Arrondo, E., Sánchez-Zapata, J.A., Donázar, J.A. 2020. Rewildling processes shape the use of Mediterranean landscapes by an avian top scavenger. Sci. Rep. 10: 2853.

Martínez-Abraín, A., 2018. Satellite factors influencing the impact of recreational activities on wildlife. Anim. Conserv. 21, 461-462.

Martínez-Abraín, A., Galán, P., 2017. A test of the substitution-habitat hypothesis in amphibians. Conserv. Biol. 32, 725-730.

Martínez-Abraín, A., Jiménez, J., 2016. Anthropogenic areas as incidental substitutes for original habitat. Conserv. Biol. 30, 593-598.

Martínez-Abraín, A., Jiménez, J., 2019a. Stick supply to nests by cliff-nesting raptors as an evolutionary load of tree nesting. Ideas in Ecology and Evolution 12, 21-25.

Martínez-Abraín, A., Jiménez, J., 2019b. Dealing with growing forest insect pests: the role of top-down regulation. J. Appl. Ecol. 56, 2574-2576.

Martínez-Abraín, J., \& Oro, D. 2018. Nocturnality decreases under low human disturbance conditions. Science (E-Letter) http://science.sciencemag. org/content/360/6394/1232/tab-e-letters\# (last accessed 29.09.20). 
Martínez-Abraín, A., Crespo, J., Jiménez, J., Gómez, J.A., Oro, D., 2009. Is the historical war against wildlife over in Southern Europe? Anim. Conserv. 12, 204-208.

Martínez-Abraín, A., Crespo, J., Berdugo, M., Gutiérrez, L., Lafuente, A., Mañas, A., de Miguel, J.M., 2013. Causes of human impact to protected vertebrate wildlife parallel long-term socio-economical changes in Spain. Anim. Conserv. 16, 286-294.

Martínez-Abraín, A., Jiménez, J., Oro, D., 2019a. Pax Romana: "refuge abandonment" and spread of fearless behaviour in a reconciling world. Anim. Conserv. 22, 3-13.

Martínez-Abraín, A., Jiménez, J., Oro, D., 2019b. New policies for a new wildlife: A road map for the wildlife manager of the future. Biol. Conserv. 236, 484-488.

Martínez-Abraín, A., Jiménez, J., Ferrer, M., 2020. Changes from cliff to tree nesting in raptors: a response to lower human persecution? J. Raptor Res. (in press).

Ministerio de Agricultura. 1962. Control de animales dañinos: información estadística. Folleto informativo 2. Servicio Nacional de Pesca Fluvial y Caza, Madrid.

Ministerio para la Transición Ecológica. 2018. Estrategia para la conservación del águila imperial ibérica Aquila adalberti en España y Portugal (https://www.miteco.gob.es/e $\mathrm{s} /$ biodiversidad/publicaciones/pbl-fauna-flora-estrategias-aguila.aspx) (last accessed 29.09.20).

Morandini, V., de Benito, E.G., Newton, I., Ferrer, M., 2017. Natural expansion versus translocation in a previously human-persecuted bird of prey. Ecol. Evol. 7, 3682-3688.

Moreno, S., Villafuerte, R., 1995. Traditional management of scrubland for the conservation of rabbits Oryctolagus cuniculus and their predators in Doñana National Park. Spain. Biol. Conserv. 73, 81-85.

Muntaner, J., 2019. Milanos reales urbanos en la isla de Mallorca. Quercus 399, 12-15.

Murgui, E., Hedblom, M. (Eds.), 2017. Ecology and Conservation of Birds in Urban Environments. Springer, Cham.

Nores C, \& Naves J. 1993. Distribución histórica del oso pardo en la Península Ibérica, in: Naves J, Palomero, G., (Eds), El Oso Pardo (Ursus arctos) en España. Madrid: ICONA, Colección Técnica, pp. 13-34.

Oberosler, V., Groff, C., Iemma, A., Pedrini, P., Rovero, F. 2017. The influence of human disturbance on occupancy and activity patterns of mammals in the Italian Alps from systematic camera trapping. Mamm. Biol., 87: 50-61.

Oro, D., Genovart, M., Tavecchia, G., Fowler, M., Martínez-Abraín, A., 2013. Ecological and evolutionary implications of food subsidies from humans. Ecol. Lett. 16, $1501-1514$.

Palomero, G., 2007. Ursus arctos. Ficha Libro Rojo. In: Palomo, L.J., Gisbert, J., Blanco, J. C. (Eds.), Atlas y Libro Rojo de los Mamíferos Terrestres de España. Dirección General para la Biodiversidad-SECEM-SECEMU, Madrid, pp. 324-326.

Palomero, G., Ballesteros, F., Herrero, J., Nores, C. (Eds.)., 2006. Demografía, distribución, genética y conservación del oso pardo cantábrico. Fundación Oso pardo. Dirección General para la biodiversidad. Ministerio de Medio Ambiente, Madrid.

Pedroso, N.M., Sales-Luís, T., Santos-Reis, M., 2007. Use of Aguieira dam by Eurasian otters in Central Portugal. Folia Zool. 56, 365-377.

Pereira, H., Navarro, M. 2015. Rewilding European landscapes. SpringerLink (https://li nk.springer.com/book/10.1007/978-3-319-12039-3) (last accessed 29.09.20).

Pérez, T., Naves, J., Vázquez, J.F., Seijas, J., Corao, A., Albornoz, J., Domínguez, A., 2010. Evidence for improved connectivity between Cantabrian brown bear subpopulations. Ursus 21, 104-108.

Pérez-Pintos, X., 2009. Historia contemporánea da destrucción da natureza en Galiza. Edicions A Nosa Terra, Vigo.

Planella, A., Jiménez, J., Palomero, G., Ballesteros, F., Blanco, J.C., López-Bao, J.V., 2019. Integrating critical periods for bear cub survival into temporal regulations of human activities. Biol. Conserv. 236, 489-495.

Preiss, E., Martin, J.L., Debussche, M., 1997. Rural depopulation and recent landscape changes in a Mediterranean region: consequences to the breeding avifauna. Landsc. Ecol. 12, 51-61.

Prugh, L.R., Stoner, C.J., Epps, C.W., Bean, W.T., Ripple, W.J., Laliberte, A.S., Brashares, J.S., 2009. The rise of the mesopredator. BioScience 59, 779-791.
Rebolo-Ifrán, N., Carrete, M., Sanz-Aguilar, A., Rodríguez-Martínez, S., Cabezas, S., Marchant, T.A., Bortolotti, G.R., Tella, J.L., 2015. Links between fear of humans, stress and survival support a non-random distribution of birds among rural and urban habitats. Sci. Rep. 5, 13723.

Rico, M., Torrente, J.P., 2000. Caza y rarificación del lobo en España: investigación histórica y conclusiones biológicas. Galemys 12, 163-179.

Riyahi, S., Sánchez-Delgado, M., Calafell, F., Monk, D., Senar, J.C., 2015. Combined epigenetic and intraspecific variation of the DRD4 and SERT genes influence novelty seeking behaviour in great tit Parus major. Epigenetics 106, 516-525.

Robinson, R.A., Sutherland, W.J., 2002. Post-war changes in arable farming and biodiversity in Great Britain. J. Appl. Ecol. 39, 157-176.

Rodríguez, A., Delibes, M., 1990. El lince ibérico (Lynx pardina) en España. Distribución y problemas de conservación. ICONA-CSIC, Madrid.

Rojo, L.I., Ezquerra, F.J., Gordo, F.J., Azcárate, J.M. 2013. Colonización por el águila imperial ibérica (Aquila adalberti Brehm) de montes intensamente gestionados en la provincia de Valladolid. In Actas del 6 Congreso Forestal Español (10-14 junio): 2-16. Vitoria-Gasteiz (Ed.). Vitoria-Gasteiz: Sociedad Española de Ciencias Forestales.

Ruiz-Olmo, J., Batet, A., Mañas, F., Martínez-Vidal, R., 2011. Factors affecting otter (Lutra lutra) abundance and breeding success in freshwater habitats of the northeastern Iberian Peninsula. Eur. J. Wildl. Res. 57, 827-842.

Sáenz de Buruaga, M., Canales, F., Campos, M.A., Navamuel, N., 2018. Lobos: Población de Castilla y León y situación en España. Editorial Rimpego, León.

Salaverri, L., Guitián, J., Munilla, I., Sobral, M., 2019. Bird richness decreases with the abandonment of agriculture in a rural region of SW Europe. Reg. Environ. Chang. 19, 245-250.

Salvatori, V., Balian, E., Blanco, J.C., Ciucci, P., Demeter, L., Hartel, T., Marsden, K., Mark Redpath, S., von Korff, Y., Claire Young, J., 2020. Applying participatory processes to address conflicts over the conservation of large carnivores: understanding conditions for successful management. Front. Ecol. Evol. 30 https:// doi.org/10.3389/fevo.2020.00182.

San Miguel-Ayanz, A., Perea García-Calvo, R., García-Olalla, M., 2010. Wild ungulates vs extensive livestock. Looking back to face the future. Options Méditérr. 92, 27-34.

SEO, 1981. Primer censo de buitreras (1979). Ardeola 26-27, 165-312.

Silliman, B.R., Hughes, B.B., Gaskins, L.C., He, Q., Tinker, M.T., Read, A., Nifong, J., Stepp, R., 2018. Are the ghosts of nature's past haunting ecology today? Curr. Biol. 28, R527-R548.

Sobrino, R., Acevedo, P., Escudero, M.A., Marco, J., Gortázar, C., 2009. Carnivore population trends in Spanish agrosystems after the reduction in food availability due to rabbit decline by rabbit haemorrhagic disease and improved waste management. Eur. J. Wildl. Res. 55, 161-165.

Stefanescu, C., Herrando, S., Páramo, F., 2004. Butterfly species richness in the northwest Mediterranean Basin: the role of natural and human-induced factors. J. Biogeogr. 31, 905-915.

Stefanescu, C., Peñuelas, J., Filella, I., 2009. Rapid changes in butterfly communities following the abandonment of grasslands: a case study. Insect Conserv. Diver. 2, 261-269.

Torrente, J.P., 1999. Osos y otras fieras en el pasado de Asturias. Fundación Oso de Asturias, Oviedo.

Vanpé, C., Palazón, S., Jonozovic, M., Afonso, I., Jato, R., Sola, J., Artazkotz, R., Batet, A., Camarra, J.J., Sentilles, J., Guinot-Gesthem, M., Quenette, P.Y., 2019. The conservation success story of a cross-border large carnivore population trough two decades of European multi-scale cooperation efforts. In: 29th International Congress for Conservation Biology ICCB. Kuala Lumpur (Malaysia).

Wiegand, T., Naves, J., Stephan, T., Fernández, A., 1998. Assessing the risk of extinction for the brown bear (Ursus arctos) in the Cordillera Cantabrica, Spain. Ecol. Monogr. 68, 539-570. 